Volume 1 Nomor 2 Edisi Desember 2013
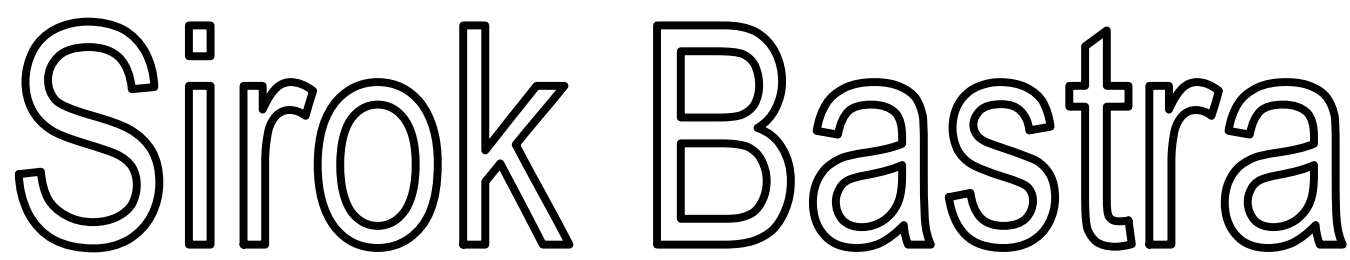

J URNAL ILMIAH KEBAHASAAN DAN KESASTRAAN

\begin{tabular}{|c|c|c|c|c|c|}
\hline $\begin{array}{c}\text { Sirok Bastra } \\
\text { Jurnal Kebahasaan dan } \\
\text { Kesastraan }\end{array}$ & Volume 1 & Nomor 2 & $\begin{array}{c}\text { Hlm. } \\
123-249\end{array}$ & $\begin{array}{c}\text { Pangkalpinang, } \\
\text { Desember } \\
2013\end{array}$ & $\begin{array}{c}\text { ISSN } \\
2354-7200\end{array}$ \\
\hline
\end{tabular}

KANTOR BAHASA KEPULAUAN BANGKA BELITUNG 

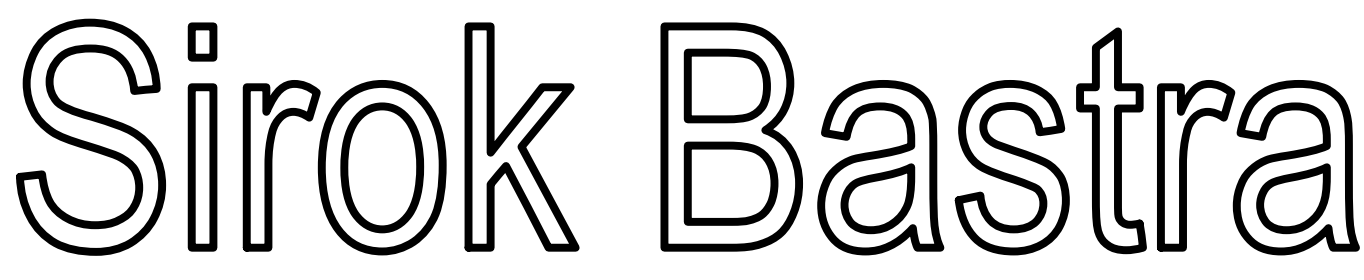

\section{J URNAL ILMIAH KEBAHASAAN DAN KESASTRAAN}

Jurnal ini merupakan wadah informasi mengenai kebahasan, kesastraan, dan pengajarannya yang memuat hasil penelitian, studi kepustakaan, dan tulisan ilmiah bidang kebahasan, kesastraan, dan pengajarannya. Jurnal ini terbit dua kali setahun, yakni Juni dan Desember, serta terbit sejak Juni 2013.

\section{Penanggung Jawab}

Kepala Kantor Bahasa Provinsi Bangka Belitung

Drs. Umar Solikhan, M.Hum.

\section{Mitra Bestari}

Prof. Dr. Agus Nuryatin, M.Hum. (Bidang Bahasa dan Pengajarannya)

Prof. Amrin Saragih, Ph.D., M.A. (Bidang Sastra dan Pengajarannya)

Dr. Felicia Nuradi Utorodewo, M.Hum. (Bidang Bahasa dan Pengajarannya)

Dr. Pujiharto, M.Hum. (Bidang Sastra dan Pengajarannya)

\section{Pemimpin Redaksi}

Rahmat Muhidin, S.S.

\section{Penyunting}

Prima Hariyanto, S.Hum.

\section{Perancang Sampul}

Feri Pristiawan, S.S.

\section{Kesekretariatan}

Khaliffitriansyah, S.Pd. Dea Letriana Cesaria, S.Hum.

Lia Aprilina, S.Pd.

Andrian Priyatno, A.Md.

Elzam

\section{Alamat Redaksi dan Penerbit}

Kantor Bahasa Provinsi Bangka Belitung

Ruko Permata 7, Jalan Solihin G.P. Km 4, Pangkalpinang, Kep. Bangka Belitung

Telp./Faks.: 0717-438455, Pos-el: sirokbastra@gmail.com

Pemuatan suatu tulisan dalam jurnal ini tidak berarti redaksi menyetujui isi tulisan tersebut. Isi tulisan menjadi tanggung jawab penulis. Tulisan telah ditinjau oleh mitra bestari. Setiap karangan dalam jurnal ini dapat diperbanyak setelah mendapat izin tertulis dari penulis, redaksi, dan penerbit. 


\section{KATA PENGANTAR}

Puji syukur ke hadirat Pemilik dan Pencipta semesta ini yang memiliki kuasa atas diri-Nya sendiri. Dialah Tuhan Yang Maha Esa yang telah memberikan rahmat dan hidayah-Nya sehingga Volume 1 Nomor 2 Jurnal Sirok Bastra dapat terbit tepat pada waktunya.

Pada nomor kedua ini, dimuat sebelas tulisan, yakni enam tulisan kebahasaan, empat kesastraan, dan satu pengajaran sastra. Dari segi bahasa, sebagian besar tulisan disajikan dalam bahasa Indonesia, hanya dua tulisan yang disajikan dalam bahasa Inggris. Kami mengucapkan terima kasih kepada para penulis yang telah bersedia menerbitkan karya mereka pada edisi ini. Para penulis merupakan para peneliti, pakar, dosen, dan mahasiswa dari berbagai perguruan tinggi dan instansi. Terima kasih juga kami sampaikan kepada para mitra bestari kami yang telah memberi ulasan terhadap tulisan-tulisan yang masuk ke redaksi.

Demi memenuhi keberagaman isi dan penulis, Sirok Bastra membuka kesempatan bagi para peneliti dan penulis menyampaikan hasil penelitian dan pemikiran mutakhir dalam bidang kebahasaan, kesastraan, dan pengajarannya.

Pangkalpinang, Desember 2013

Tim Redaksi 


\section{UCAPAN TERIMA KASIH UNTUK MITRA BESTARI}

Redaksi Sirok Bastra mengucapkan terima kasih kepada para mitra bestari yang telah meninjau, menimbang, dan mengulas makalah-makalah yang diterbitkan dalam Sirok Bastra Volume 1 Nomor 2, edisi Desember 2013, yakni

Prof. Dr. Agus Nuryatin, M.Hum.

Bidang Sastra dan Pengajarannya

Universitas Negeri Semarang

Semarang, Jawa Tengah

Prof. Amrin Saragih, Ph.D., M.A.

Bidang Bahasa dan Pengajarannya

Universitas Negeri Medan

Medan, Sumatra Utara

Dr. Felicia Nuradi Utorodewo, M.Hum.

Bidang Bahasa dan Pengajarannya

Universitas Indonesia

Depok, Jawa Barat

\section{Dr. Pujiharto, M.Hum.}

Bidang Sastra dan Pengajarannya

Universitas Gadjah Mada

Yogyakarta, Daerah Istimewa Yogyakarta 


\section{DAFTAR ISI}

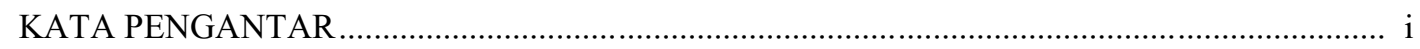

UCAPAN TERIMA KASIH UNTUK MITRA BESTARI .................................................... ii

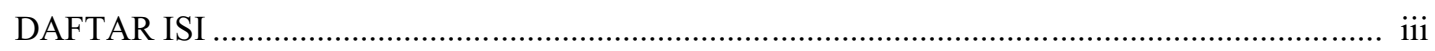

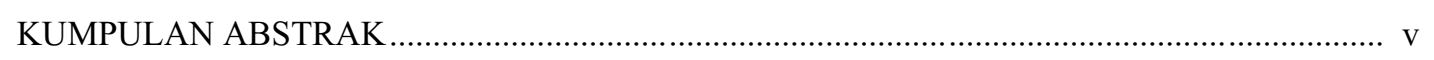

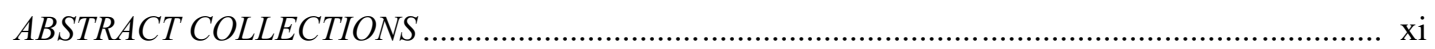

BAHASA INDONESIA DALAM INFORMASI DAN IKLAN DI RUANG PUBLIK KOTA PANGKALPINANG

(Indonesian in Information and Advertising in Public Space Pangkalpinang)

Umar Solikhan $123-129$

PERBEDAAN MAKNA NOMINA BERAFIKS $P E-, P E R-, P E--A N$, DAN $P E R--A N$ DALAM NASKAH HIKAYAT BAYAN BUDIMAN, HIKAYAT MUHAMMAD HANAFIYYAH, DAN HIKAYAT RAJA PASAI

(Affixed Noun Meaning Differences of pe-, per-, pe--an, and per--an in The Hikayat Bayan Budiman, Hikayat Muhammad Hanafiyyah, and Hikayat Raja Pasai Manuscripts)

Rindias H. Fatmasari $131-147$

WACANA RUBRIK INTIMATE DI MAJALAH DIGITAL INTERAKTIF MALE

(Intimate Rubric in Male Digital Interactive Magazine Discourse)

Prima Hariyanto $149-160$

AN ACOUSTICAL CONTRASTIVE ANALYSIS OF SUNDANESE CENTRAL VOWELS (Analisis Konstrastif Akustik Vokal Pusat Bahasa Sunda)

Yusup Irawan. $161-175$

KATA SUDAH SEBAGAI PENANDA ASPEK DENGAN AWALAN TER-

The Word of Sudah as An Aspect with Prefix Ter-

Dea Letriana Cesaria $177-182$

PERUBAHAN DAN PERGESERAN MAKNA DALAM KATA-KATA BERDERIVASI NOMINA KE VERBA YANG MENGANDUNG AFIKS $M E(N)-, M E(N)-K A N$, DAN $M E(N)-I$ PADA SURAT KABAR HARIAN KOMPAS

(Change and Shift of Meaning in The Derivated Words Nomine to Verb That Contain Affixes $m e(N)-$, me(N)-kan, dan me(N)- $i$ in The Kompas The Daily Newspaper)

Teodora Nirmala Fau $183-193$

MENCIPTA-KREATIF NASKAH DRAMA DENGAN STRATEGI MENULIS TERBIMBING (Creative Writing of Playscript eith Guided Writing Strategy)

Sony Sukmawan. $195-205$ 
PENGARUH KONSEP HAGABEON, HAMORAON, DAN HASANGAPON TERHADAP

KETIDAKSETARAAN GENDER DALAM AMANG PARSINUAN

(The Influence of Hagabeon, Hamoraon, and Hasangapon Concept for Gender Inequality in Amang Parsinuan)

Fransiska Simangunsong $207-220$

PERSPEKTIF PENGARANG MENGENAI RELASI ANTARA MANUSIA DAN

LINGKUNGAN HIDUP DALAM NOVEL PARTIKEL KARYA DEWI LESTARI: SEBUAH KAJIAN EKOKRITISISME

(Author's Perspective on The Relationship Between Humans and The Environment in The Novel Partikel Written by Dewi Lestari: an Ecocriticism Studies)

Alfi Yusrina Ramadhani $221-229$

FENOMENA HUKUM ADAT BALI TERHADAP BAYI KEMBAR BUNCING DALAM

NOVEL INCEST KARYA I WAYAN ARTIKA

Bali Custom Law Phenomenon of Kembar Buncing Infant in I Wayan Artika Novel Incest Annisa Aprinandri Irwin dan Khansa Khairunnisa $231-241$

RELIGIOUS AND MORAL VALUES IN MADURA FOLKTALES

Religiositas dan Nilai Moral dalam Cerita-Cerita Rakyat Madura

Imron Wakhid Harits. $243-249$ 


\title{
PERUBAHAN DAN PERGESERAN MAKNA DALAM KATA-KATA BERDERIVASI NOMINA KE VERBA YANG MENGANDUNG AFIKS $M E(N)$-, ME(N)-KAN, DAN $M E(N)$-I PADA SURAT KABAR HARIAN KOMPAS
}

\section{Change and Shift of Meaning in The Derivated Words Nomine to Verb That Contain Affixes me(N)-, $m e(N)-k a n$, dan $m e(N)-i$ in The Kompas The Daily Newspaper}

\section{Teodora Nirmala Fau}

Fakultas Ilmu Pengetahuan Budaya, Universitas Indonesia

Kampus Baru UI Depok, Jawa Barat

pos-el: teodoranirmala@gmail.com

(diterima 2 Agustus 2013, disetujui 30 September 2013, revisi terakhir 26 November 2013)

\begin{abstract}
Abstrak
Topik penelitian ini adalah derivasi nomina ke verba yang ditemukan pada surat kabar harian Kompas. Derivasi yang ada dalam surat kabar harian tersebut meliputi derivasi dari segi kelas kata dan makna. Derivasi dari segi kelas dapat dilihat dari pemberian afiks pembentuk verba, sedangkan derivasi dari segi makna dapat dilihat dari perubahan dan pergeseran makna kata turunan dengan kata asalnya. Perubahan dan pergeseran tersebut dapat dibagi menjadi dua jenis, yaitu idiom dan metafora. Ada 20 jenis idiom dan 24 jenis metafora yang ditemukan dalam surat kabar harian tersebut. Karakteristik dari kata berderivasi nomina ke verba ini dapat dilihat dari kemampuan mereka untuk dipasifkan. Hasilnya, mereka memiliki enam karakteristik.
\end{abstract}

Kata kunci: derivasi, afiks, idiom, metafora, dan karakteristik

\section{Abstract}

This research about derivation of nomines to verbs in Kompas the daily newspaper. That things include derivation of category and meaning. Derivation of category could be seen from nomine that adhered affix to verb-formation while derivation of meaning could be seen from change and shift of meaning about complex words to their bases. It been devided in two kinds. Those are idioms and metaphors. There are 20 kinds of idioms and 24 kinds of metaphors. Characteristic of it could be seen from ability change into pasif verb. They have 6 characteristic about that.

Key words: derivation, affix, idioms, metaphors, and characteristic

\section{PENDAHULUAN}

\subsection{Latar Belakang}

Sifat bahasa yang dinamis membuat bahasa terus berubah dari waktu ke waktu. Salah satu bentuk perubahan bahasa dapat dilihat dari muncul atau hilangnya semua lema dari kamus yang satu terhadap kamus yang lainnya. Sebagai contoh, di dalam Kamus Umum Bahasa Indonesia karya Poerwadarminta (1960) tidak terdapat kata unggah dan unduh, tetapi kedua kata tersebut ditemukan dalam Kamus Besar Bahasa Indonesia Edisi Ketiga (2007). Meskipun demikan, perubahan bahasa tidak berhenti pada pemunculan atau penghilangan lema-lema dalam kamus. Perubahan bahasa dapat dilihat pula dari pergantian atau pengalihan rujukan terhadap sebuah kata lama dengan konsep baru yang ada di masyarakat bahasa.

Pergantian rujukan sebuah kata yang telah ada dengan konsep yang baru menandakan ada derivasi. Derivasi adalah perubahan morfemis yang menghasilkan kata dengan identitas morfemis yang lain (Verhaar, 2010: 143). Perubahan morfemis yang dimaksud Verhaar dapat dibagi menjadi dua, yaitu perubahan kategori kata dan perubahan makna kata. Pergantian rujukan sebuah kata mengarah pada perubahan makna kata. Pergantian rujukan ini dapat terjadi pada kata-kata turunan, khususnya yang melekat dengan afiks. Subroto (2005: 15) menyatakan bahwa afiksasi sering menyebabkan sebuah makna turunan memiliki keanehan semantis dengan makna lesikalnya.

Penelitian ini membahas mengenai kedua jenis 
derivasi yang digolongkan oleh Verhaar, yaitu perubahan kategori kelas dan perubahan makna. Berdasarkan pernyataan Subroto di atas, peneliti memiliki kecurigaan bahwa kata-kata berafiks memiliki derivasi makna, khususnya verba berafiks yang berasal dari kelas nomina. Kecurigaan terhadap pergantian rujukan yang dialami oleh verba berafiks yang berasal dari nomina disebabkan oleh sifat nomina yang memiliki fitur-fitur semantik yang selalu melekat pada katanya sehingga akan menimbulkan keganjilan jika diberi proses morfologi (Alwi dkk., 2003: 214). Pemilihan verba juga berdasarkan alasan bahwa keberadaan verba hampir selalu ada di dalam kalimat.

\subsection{Masalah}

1. Bagaimana perubahan dan pergeseran makna kata-kata yang berderivasi nomina ke verba pada surat kabar harian Kompas?

2. Bagaimana karakterisitik kata-kata berderivasi nomina ke verba yang mengalami perubahan ataupun pergeseran makna tersebut?

\subsection{Tujuan}

1. Menganalisis dan menginventarisasi kata-kata berderivasi nomina ke verba yang mengandung afiks $m e(N)$-, $m e(N)-k a n$, dan $m e(N)-i$ yang mengandung perubahan ataupun pergeseran makna pada surat kabar harian Kompas.

2. Melihat karakteristik dari kata-kata berderivasi nomina ke verba yang mengalami perubahan atau pergeseran makna.

\subsection{Manfaat}

Dari hasil penelitian ini, dapat dilihat bagaimana perkembangan bahasa Indonesia pada saat ini yang ada di surat kabar harian Kompas. Lebih khususnya, penelitian ini melihat perkembangan makna yang meliputi perubahan dan pergeseran makna pada kata-kata berderivasi nomina ke verba. Dari hasil tersebut, dapat diperoleh manfaat mengenai data perkembangan bahasa secara diakronik yang dapat dijadikan sebagai landasan penelitian lanjutan mengenai perkembangan bahasa Indonesia dari waktu ke waktu.

\subsection{Metode}

Penelitian mengenai perubahan dan pergeseran makna berderivasi nomina ke verba ini dapat digolongkan ke dalam jenis penelitian yang bersifat analisis-ekspositoris. Peneliti akan lebih banyak memaparkan hasil analisisnya terhadap data berdasarkan sintesis teori dari beberapa ahli. Jenis penelitian ini erat kaitannya dengan metode penelitian yang dipilih oleh penulis, yaitu metode kualitatif. Metode kualitatif yang digunakan pada penelitian ini dapat digolongkan sebagai metode kualitatif yang bersumber pada bahan-bahan pustaka. Pada penelitian ini, sumber pustaka yang dijadikan sebagai rujukan utama adalah Kamus Besar Bahasa Indonesia Edisi Ketiga (KBBI 3).

Data penelitian ini adalah surat kabar harian Kompas tertanggal 14 Januari 2013. Bahasa di surat kabar harian yang menggunakan laras jurnalistik dianggap dapat menggambarkan situasi kebahasaan di masyarakat (Sarwoko, 2007: 6). Kompas dipilih menjadi korpus data karena surat kabar harian ini merupakan surat kabar nasional yang tingkat penyebarannya telah sampai ke bagian timur Indonesia, oplahnya yang tinggi, serta jumlah pembaca yang melebihi surat kabar harian lain (http://jogja-adv.com/strategi-beriklan/strategi-promo si/770/oplah-harian-kompas/, diunduh 10 Maret 2013 pukul 19.32). Dari alasan-alasan tersebut, ada asumsi bahwa bahasa di surat kabar harian Kompas dengan bahasa Indonesia yang ada di masyarakat saling terpengaruhi.

\section{KERANGKA TEORI}

\subsection{Derivasi}

Untuk penelitian ini, teori yang menjadi dasar penelitian adalah teori derivasi dari Verhaar (2010: 143) yang menyatakan bahwa derivasi adalah perubahan morfemis yang menghasilkan kata dengan identitas morfemis yang lain. Maksud dari identitas morfemis menurut Verhaar adalah perubahan kelas kata dan perbedaan makna dari kata yang sama, baik melalui proses morfologi atau tanpa proses morfologi. Di dalam teorinya mengenai derivasi, perubahan kelas kata secara tidak langsung menandakan adanya derivasi pada kata sekaligus turut membedakan maknanya secara leksikal ataupun gramatikal.

Selain menggunakan pendapat Verhaar, penelitian ini juga menggunakan pendapat Booij dalam 
membedakan antara derivasi dan infleksi. Infleksi memang erat dikaitkan dengan derivasi, namun Booij memaparkan secara terperinci mengenai perbedaan keduanya. Secara umum, Booij membedakan derivasi dan infleksi ke dalam empat perbedaan, yaitu menurut kewajiban pemakaiannya, pergantian kelas kata dalam unsur sintaksis, paradigma, dan perbedaan semantisnya (2006: 655-657).

\subsection{Sintesis Kemungkinan Pemaknaan Afiks} Pembentuk Verba: $m e(N)-$, me(N)-kan, dan $m e(N)-i$

Penelitian mengenai derivasi nomina ke verba ini erat kaitannya dengan perubahan kelas kata dan makna. Dari segi perubahan kelas kata, perubahan morfemis terjadi dari kata dasar berkelas nomina menjadi verba akibat ada pelekatan afiks pembentuk verba pada kata tersebut. Di bawah ini adalah afiks-afiks pembentuk verba yang peneliti dapatkan dari konsep para linguis, yaitu Ramlan (2001), Abdul Chaer (2008), Harimurti Kridalaksana (2009), Masnur Muslich (2009), serta Zaenal Arifin dan Junaiyah (2009) serta yang ditemukan pada surat kabar harian Kompas tertanggal 14 Januari 2013.

Tabel 1 Perbandingan Afiks Pembentuk Verba

\begin{tabular}{|c|c|c|c|c|c|c|}
\hline No. & $\begin{array}{c}\text { Afiksasi } \\
\text { Pembentuk Verba }\end{array}$ & Ramlan & $\begin{array}{l}\text { Abdul } \\
\text { Chaer }\end{array}$ & $\begin{array}{c}\text { Harimurti } \\
\text { Kridalaksana }\end{array}$ & $\begin{array}{l}\text { Masnur } \\
\text { Muslich }\end{array}$ & $\begin{array}{r}\text { Zaenal Arifin } \\
\text { \& Junaiyah }\end{array}$ \\
\hline 1. & Prefiks ber- & + & + & + & + & + \\
\hline 2. & Konfiks/Konflik ber-an & & + & + & + & + \\
\hline 3. & Konfiks ber-...-kan & & + & + & & \\
\hline 4. & Sufiks -kan & + & + & & + & + \\
\hline 5. & Sufiks $-\mathrm{i}$ & + & + & 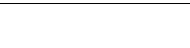 & + & + \\
\hline 6. & Prefiks per-/peng- & & + & + & + & + \\
\hline 7. & Konfiks per-kan & & + & + & & \\
\hline 8. & Konfiks per-i & & + & + & & \\
\hline 9. & Prefiks me(N)- & + & + & + & + & + \\
\hline 10. & Konfiks me(N)-kan & + & & + & + & \\
\hline 11. & Konfiks me(N)-i & + & & + & + & \\
\hline 12. & Konfiks memper- & & & + & & \\
\hline 13. & Konfiks memper-kan & & & + & & \\
\hline 14. & Konfiks member-kan & & & & & \\
\hline 15. & Konfiks meke-kan & & & & & \\
\hline 16. & Konfiks mense-i & & & & & \\
\hline 17. & Prefiks di- & + & + & & + & + \\
\hline 18. & Konfiks di-i & + & & + & & \\
\hline 19. & Konfiks di-kan & + & & & & \\
\hline 20 & Konfiks diper- & & & + & & \\
\hline 21. & Konfiks diper-kan & & & + & & \\
\hline 22. & Prefiks ter- & + & + & + & + & + \\
\hline 23. & Konfiks ter.-i & + & & & & \\
\hline 24. & Konfiks ter-kan & + & & & & \\
\hline 25. & Prefiks ke- & & + & + & & \\
\hline 26. & Konfiks ke-an & & + & + & & + \\
\hline 27. & Simulfiks n- & & & + & & \\
\hline 28. & Konfiks n-in & & & + & & \\
\hline 29. & Sufiks -in & & & + & & \\
\hline 30. & Sufiks -an & & & & & + \\
\hline \multicolumn{7}{|c|}{$\begin{array}{l}\text { Keterangan: } \\
\text { “+” menunjukkan afiks tersebut ada dalam konsep linguis }\end{array}$} \\
\hline
\end{tabular}

Tidak semua kata yang terindikasi mengalami perubahan ataupun pergeseran makna diteliti pada 
Teodora Nirmala Fau: Perubahan dan Pergeseran Makna dalam Kata-Kata ...

penelitian ini. Hal tersebut disebabkan keterbatasan waktu. Peneliti memfokuskan analisis pada kata-kata yang terindikasi mengalami perubahan ataupun pergeseran makna yang mengandung afiks me(n)-, $m e(n)-k a n$, dan me(n)-i. Pemilihan afiks yang mengandung me(n)- disebabkan adanya temuan peneliti pada data mengenai afiks member-kan, mense-i, dan menge-kan-yang setelah dianalisi merupakan afiks me(N)-kan yang melekat pada frase eksosentris-yang tidak dibicarakan dalam konsep linguis-linguis yang menjadi landasan teori penelitian.
Pelekatan me(N)-kan pada frase eksosentris — contohnya mengedepankan — cenderung membuat makna turunan mengalami perubahan. Hal itu menjadi alasan peneliti pula untuk memfokuskan penelitian pada kata berafiks $m e(n)-, m e(n)-k a n$, dan $m e(n)-i$. Oleh karena itu, sintesis kemungkinan pemaknaan dari kelima konsep linguis hanya ditekankan pada ketiga afiks tersebut. Di bawah ini adalah tabel sintesis pemaknaan dari me(n)-, $m e(n)-k a n$, dan $m e(n)-i$.

Tabel 2 Sintesis Kemungkinan Pemaknaan Afiks Pembentuk Verba

\begin{tabular}{|c|l|l|l|}
\hline No. & \multicolumn{1}{|c|}{ Makna Prefiks $\boldsymbol{M e}(\boldsymbol{N})$ - } & \multicolumn{1}{|c|}{ Makna Konfiks Me(N)-kan } & \multicolumn{1}{|c|}{ Makna Konfiks Me(N)-i } \\
\hline 1. & Hidup di & Menganggap atau menjadikan & Melakukan \\
\hline 2. & Membuat atau menghasilkan & Membawa ke & Memberi \\
\hline 3. & Mengeluarkan (suara) & Memasukkan ke & Bersikap atau berlaku seperti \\
\hline 4. & Menuju ke & Menghasikan & Menjadkan sebagai/seperti \\
\hline 5. & Mencari atau mengumpukan & Memberi (objek) sesuatu seperti & Membuat atau menyebabkan \\
\hline 6. & Berlaku seperti atau menyerupai & & $\begin{array}{l}\text { Menganggap atau memperlakukan } \\
\text { sebagai/ada di }\end{array}$ \\
\hline 7. & Menjadi & & \\
\hline 8. & Memberi & & \\
\hline 9. & Melakukan & & \\
\hline 10. & Dalam keadaan & & \\
\hline 11. & Meminum, makan, atau menghisap & & \\
\hline 12. & Menggunakan atau memakai & & \\
\hline
\end{tabular}

Sintesis kemungkinan pemaknaan di atas akan digunakan sebagai dasar analisis untuk mencari kesesuaian makna gramatikal dengan konteks kalimat pada kata-kata yang terindikasi mengalami perubahan atau pergeseran makna.

\subsection{Idiom dan Metafora}

Pergantian rujukan pada kata-kata turunan merupakan perubahan ataupun pengalihan makna dari konsep yang lama ke konsep yang baru yang muncul di masyarakat bahasa. Pergantian rujukan ini erat kaitannya dengan bentuk metafora dan idiom. Metafora adalah jenis pemaknaan sebuah kata yang dilihat dari segi penggunaannya (Chaer, 2009: 75). Chaer memasukkan metafora sebagai suatu fenomena kebahasaannya yang gejalanya mirip dengan makna idiom. Namun, jika diteliti keduanya memiliki perbedaan.

Chaer (2009: 75-76) menyatakan bahwa sebuah kata yang bersifat metafora adalah kata-kata yang maknanya mengambil perbandingan dengan makna leksikalnya, namun tidak makna leksikal secara keseluruhan dari kata tersebut. Untuk idiom, Chaer (2009: 74) menyatakan "Makna idiom ini tidak lagi berkaitan dengan makna leksikal atau makna gramatikal unsur-unsurnya..." Ketidaketerkaitan sebuah kata bermakna idiom dengan makna leksikal atau gramatikalnya menandakan tidak ada pengambilan aspek komponen makna kata dasar terhadap kata turunan yang dihasilkan. Hal ini tidak berlaku untuk kata bermakna metafora. Berdasarkan keterangan dari Chaer, dapat disimpulkan bahwa ada pengambilan aspek komponen makna kata dasar ataupun perbandingan makna turunan terhadap aspek komponen makna kata dasarnya.

Pembatasan antara metafora dan idiom dapat dilihat pula dari pendapat Lakeoff dan Johnson. Menurut Lakeoff dan Johnson (1980: 5), inti dari metafora adalah pengalihan dari satu hal ke hal yang lain. Pengalihan tersebut menghasilkan makna yang bergeser dari makna leksikalnya. Pergeseran makna tersebut disebabkan karena makna metafora hanya 
mengalihkan satu konsep ke konsep lain dengan menggunakan sifat-sifat dari konsep yang dialihkan. Adapun pernyataan tersebut dapat dilihat pada kutipan, "Metaphorical structuring involved here is partial, not total. If it were total, one copcept would actually be the other, not merely be understand interms of it" (Lakeoff dan Johnson, 1980: 13). Dari pendapat tersebut dapat dipastikan bahwa makna metafora pasti mengandung makna leksikal meskipun tidak menyeluruh. Hal ini yang tidak didapati pada bentuk idiom.

Gorys Keraf (dalam Sarwoko, 2007: 115) menyatakan bahwa makna idiom tidak dapat ditangkap melalui kata yang membentuknya. Hal ini menunjukkan idiom sama sekali tidak mengambil satu aspek komponen makna pun dari kata dasar yang membentuknya. Jadi, idiom merupakan perubahan rujukan kata dengan konsep baru yang bergantung pada konteks kalimat yang melingkupinya.

Dari analisis di atas, dapat dibedakan penciri antara metafora dengan idiom. Penciri dari metafora adalah pengambilan atau perbandingan sedikitnya salah satu aspek komponen makna dasar untuk kata turunan. Makna kata-kata yang bermetafora hanya bergeser dalam makna kata dasarnya. Penciri dari idiom adalah pembentukan makna baru yang tidak mengambil satu aspek komponen makna pun dari bentuk dasarnya. Karena hal tersebut, terjadi perubahan rujukan dari makna dasar terhadap kata turunannya.

\section{HASIL DAN PEMBAHASAN}

\subsection{Perubahan dan Pergeseran Makna dalam Kata-Kata Berderivasi Nomina ke Verba}

Di dalam surat kabar harian Kompas tertanggal 14 Januari 2013, ada 4.987 verba berafiks yang diteliti.
Dari jumlah tersebut, verba yang berasal dari nomina-yang berarti mengalami derivasi kategori kata-sebanyak 1.044 kata, 20, 93\% dari total verba berafiks yang ada di surat kabar harian itu. Penentuan sebuah kata merupakan verba dapat dilihat dari afiks yang melekat pada kata, sedangkan penentuan nominanya dapat dirujuk pada Kamus Besar Bahasa Indonesia Edisi Ketiga (2007).

Peneliti menemukan 165 verba yang terindikasi mengalami pergantian rujukan dari kata asalnya. Pergantian rujukan tersebut dapat dibagi menjadi dua jenis, yaitu idiom dan metafora. Dalam menentukan sebuah kata memiliki sifat idiomatis atau metaforis. Tahap awal yang dilakukan peneliti adalah memasangkan kata tersebut dengan sintesis kemungkinan-kemungkinan pemaknaan afiks yang didapat peneliti dari perbandingan konsep para linguis mengenai afiks me(n)-, me(n)-kan, dan me(n)-i. Di bawah ini adalah sintesis kemungkinan pemaknaan dari ketiga afiks tersebut.

Dalam analisis, tidak semua kemungkinan pemaknaan afiks digunakan pada sebuah kata. Hanya kemungkinan pemaknaan afiks yang sesuai untuk dipasangkan dengan kata tersebut yang dianalisis kesesuaiannya dengan konteks kalimat. Jika tidak didapatkan kesesuaian, peneliti mencari makna baru untuk kata tersebut berdasarkan hubungan paradigmatik yang dapat dilakukan melalui proses substitusi. Dari makna yang didapat, peneliti baru dapat menentukan kata turunan tersebut tergolong bersifat idiomatis atau metaforis. Dari analisis tersebut, peneliti menemukan 20 jenis kata yang bermakna idiom dan 24 jenis kata yang bermakna metafora. Di bawah ini adalah tabel yang menunjukkan perbedaan makna kata turunan pada data dengan kata dasarnya.

Tabel 3 Derivasi Makna pada Data

\begin{tabular}{|c|c|c|c|}
\hline \multicolumn{4}{|c|}{ Derivasi Makna Bersifat Idiomatis } \\
\hline No. & Kata & Makna Asal & Makna Turunan \\
\hline 1. & membentuk & bangun, gambaran (KBBI 3: 135) & $\begin{array}{l}\text { membuat atau menjadikan } \\
\text { (sesuatu) }\end{array}$ \\
\hline 2. & menggeliat & gerakan meliuk-liuk dan melilit (KBBI 3, 2007 : 347) & mengalami kemajuan \\
\hline 3. & merakit & $\begin{array}{l}\text { kendaraan apung dibuat dari beberapa buluh (kayu) yang diikat } \\
\text { bejajar... (KBBI 3, 2007: 923) }\end{array}$ & $\begin{array}{l}\text { membuat atau menyusun } \\
\text { (sesuatu) }\end{array}$ \\
\hline 4. & mengeksekusi & pelaksanaan putusan hakim (KBBI 3, 2007: 288) & menyukseskan \\
\hline 5. & mendarat & $\begin{array}{l}\text { bagian permukaan bumi yang padat, tanah yang tidak digenangi air } \\
\text { (KBBI 3, 2007: 237) }\end{array}$ & datang atau tiba \\
\hline 6. & menyusun & kelompok atau kumpulan yang tidak berapa banyak, tumpuk & membuat atau mengatur \\
\hline
\end{tabular}


Teodora Nirmala Fau: Perubahan dan Pergeseran Makna dalam Kata-Kata ...

\begin{tabular}{|c|c|c|c|}
\hline & & (KBBI 3, 2007: 1111) & \\
\hline 7. & mencetak & cap (KBBI 3, 2007: 212) & $\begin{array}{l}\text { membuat atau menghasilkan } \\
\text { (sesuatu) }\end{array}$ \\
\hline 8. & menilai & harga, angka kepandaian, banyak sedikitnya (KBBI 3, 2007: 783) & Menganggap \\
\hline 9. & mendikte & $\begin{array}{l}\text { yang diucapkan atau dibaca keras-keras supaya ditulis orang lain } \\
\text { (KBBI 3: 2007: 265). }\end{array}$ & memegang kendali \\
\hline 10. & merupakan & $\begin{array}{l}\text { keadaan yang tampak di luar, roman muka, wujud, bangun, tokoh, } \\
\text { bentuk (KBBI 3, 2007: 971) }\end{array}$ & adalah \\
\hline 11. & menggambarkan & $\begin{array}{l}\text { tiruan barang yang dibuat dengan coretan pensil dan sebagainya } \\
\text { pada kertas dan sebagainya' (KBBI 3, 2007: 329) }\end{array}$ & $\begin{array}{l}\text { memberi anggapan bahwa } \\
\text { atau menyatakan (sesuatu) }\end{array}$ \\
\hline 12. & menempatkan & $\begin{array}{l}\text { sesuatu yang dipakai untuk menaruh (wadah)' (KBBI 3, 2007: } \\
\text { 1167) }\end{array}$ & mengirim (sesuatu) \\
\hline 13. & memusatkan & tempat yang letaknya di bagian tengah' (KBBI 3, 2007: 911) & Memfokuskan \\
\hline 14. & membuahkan & $\begin{array}{l}\text { bagian tumbuhan yang berasal dari bunga atau putik (biasanya } \\
\text { berbiji) (KBBI 3, 2007: 166) }\end{array}$ & menghasilkan (sesuatu) \\
\hline 15. & mengarahkan & jurusan, tujuan (KBBI 3, 2007: 63) & $\begin{array}{l}\text { memberikan tanda atau } \\
\text { mengubah (sesuatu) }\end{array}$ \\
\hline 16. & mengatasi & bagian yang lebih tinggi dari' (KBBI 3, 2007: 74) & $\begin{array}{l}\text { melakukan tindakan } \\
\text { penyelesaian terhadap }\end{array}$ \\
\hline 17. & menangani & $\begin{array}{l}\text { anggota badan dari siku sampai ke ujung jari atau dari pegelangan } \\
\text { tangan sampai ujung jari (KBBI 3, 2007: 1136) }\end{array}$ & mengurus (sesuatu) \\
\hline 18. & menempati & $\begin{array}{l}\text { sesuatu yang dipakai untuk menaruh (wadah) (KBBI 3, 2007: } \\
\text { 1167) }\end{array}$ & memperoleh atau tinggal di \\
\hline 19. & menyiasati & $\begin{array}{l}\text { periksa, pemeriksaan yang teliti, penyelidikan (KBBI3, 2007: } \\
1060)\end{array}$ & $\begin{array}{l}\text { membuat keputusan alternatif } \\
\text { untuk/mengenai }\end{array}$ \\
\hline 20. & menghargai & $\begin{array}{l}\text { kehormatan, guna (arti, kepentingan, kabar, dan sebagainya) } \\
\text { (KBBI 3, 2007: 358) }\end{array}$ & $\begin{array}{l}\text { memberi penghormatan } \\
\text { (kepada) }\end{array}$ \\
\hline \multicolumn{4}{|c|}{ Derivasi Makna Bersifat Metaforis } \\
\hline 21. & meningkat & $\begin{array}{l}\text { susunan yang berlapis-lapis atau berlenggek-lenggek, tinggi rendah } \\
\text { martabat (KBBI 3, 2007: 1197) }\end{array}$ & menjadi lebih tinggi/banyak \\
\hline 22. & mengular & $\begin{array}{l}\text { binatang melata, tidak berkaki, tubuhnya agak bulat memanjang, } \\
\text { kulitnya bersisik, hidup di tanah atau air, ada yang berbisa ada } \\
\text { yang tidak. (KBBI } 3,2007: 1240)\end{array}$ & memanjang \\
\hline 23. & mematok & $\begin{array}{l}\text { ukuran untuk luas tanah persawahan, pancang, tonggak (KBBI } 3 \text {, } \\
\text { 2007: 837) }\end{array}$ & memberi ukuran \\
\hline 24. & memberangus & $\begin{array}{l}\text { selongsong penutup yang terbuat dari kulit atau rotan yang } \\
\text { dianyam untuk menutup moncong anjing atau moncong anak sapi } \\
\text { (KBBI 3, 2007: 137) }\end{array}$ & menghalangi \\
\hline 25. & melangkah & $\begin{array}{l}\text { gerakan kaki (ke depan, ke belakang, ke kiri, ke kanan) waktu } \\
\text { berjalan (KBBI 3, 2007: 635) }\end{array}$ & bergerak maju \\
\hline 26. & memanen & pemungutan hasil sawah atau ladang (KBBI 3, 2007: 822) & mengumpulkan hasil (air) \\
\hline 27. & mengakar & $\begin{array}{l}\text { bagian tumbuhan yang biasanya tertanam di dalam tanah sebagai } \\
\text { penguat dan pengisap air serta zat makanan (KBBI 3: 19) }\end{array}$ & $\begin{array}{l}\text { menjadi sesuatu yang } \\
\text { didalami sejak lama }\end{array}$ \\
\hline 28. & meroket & $\begin{array}{l}\text { peluru berbentuk silinder yang digerakkan dengan reaksi motor dan } \\
\text { dapat bekerja di luar atmosfer (KBBI 3, 2007: 961) }\end{array}$ & melonjak naik \\
\hline 29. & menyengat & $\begin{array}{l}\text { alat tajam dan berbisa pada serangga dan binatang lain, seperti } \\
\text { lebah, lipan, dan kala untuk menyerang atau mempertahankan diri } \\
\text { (KBBI 3, 2007: 1035) }\end{array}$ & sangat panas/terik \\
\hline 30. & merotasi & perputaran (KBBI 3, 2007: 963) & mengatur pergantian \\
\hline 31. & menjamur & $\begin{array}{l}\text { jenis tumbuhan yang tidak berdaun dan tidak berbuah, berkembang } \\
\text { biak dengan spora, biasanya berbentuk payung...' (KBBI 3: 2007: } \\
\text { 456) }\end{array}$ & berkembang dengan pesat \\
\hline 32. & membayangkan & gambar di pikiran, angan-angan, khayal (KBBI 3, 2007: 117) & memiliki prasangka \\
\hline 33. & meningkatkan & susunan yang berlapis-lapis atau berlenggek-lenggek, tinggi rendah & memberikan \\
\hline
\end{tabular}


Teodora Nirmala Fau: Perubahan dan Pergeseran Makna dalam Kata-Kata ...

\begin{tabular}{|l|l|l|l|}
\hline & & martabat (KBBI 3, 2007: 1197) & kemajuan/tambahan (untuk) \\
\hline 34. & Mengerahkan & rodi (kewajiban bekerja) (KBBI 3, 2007: 548) & mengirim (sesuatu) \\
\hline 35. & Memasarkan & tempat orang berjual beli (KBBI 3, 2007: 833) & $\begin{array}{l}\text { menjual atau } \\
\text { mempromosikan (barang } \\
\text { dagangan) }\end{array}$ \\
\hline 36. & Mengendalikan & kekang (KBBI 3, 2007: 543) & Mengatur \\
\hline 37. & Menggoreskan & garis, garit, coret, parut (KBBI 3, 2007: 369) & Menulis \\
\hline 38. & Membalikkan & sisi yang sebelah belakang dari yang kita lihat (KBBI 3, 2007: 96) & Mengubah \\
\hline 39. & Melayari & $\begin{array}{l}\text { kain tebal untuk menadah angin agar perahu (kapal) dapat berjalan } \\
\text { (laju) (KBBI 3, 2007: 647) }\end{array}$ & Lewat \\
\hline 40. & Menyikapi & perilaku, gerak-gerik (KBBI 3, 2007: 1063) & memberi tanggapan terhadap \\
\hline 41. & Mengendarai & $\begin{array}{l}\text { Konstruksi atau kendaraan yang dirancang untuk perjalanan } \\
\text { melalui udara (KBBI 3, 2007: 543) }\end{array}$ & melakukan perjalanan dengan \\
\hline 42. & Membekali & $\begin{array}{l}\text { sesuatu yang dapat digunakan kelak apabila perlu (KBBI 3, 2007: } \\
121)\end{array}$ & $\begin{array}{l}\text { memberikan pedoman } \\
\text { kepada }\end{array}$ \\
\hline 43. & Menyelimuti & $\begin{array}{l}\text { kain penutup tubuh (terutama dipakai sewaktu tidur) (KBBI 3, } \\
\text { 2007: 1021) }\end{array}$ & menutup \\
\hline 44. & Melintasi & trayek (KBBI 3, 2007: 676) & Lewat \\
\hline
\end{tabular}

Dari 44 jenis kata bermakna idiom dan metafora di atas, hanya ada 13 jenis yang kata dasar atau kompleksnya memiliki polisemi yang mengarah pada makna kias di dalam Kamus Besar Bahasa Indonesia Edisi Ketiga. Tidak semua makna kias yang ditemukan dalam kamus memiliki keterkaitan dengan makna yang dihasilkan dari analisis berdasarkan konteks kalimat. Hanya ada empat kata yang makna idiom atau kata yang makna metaforanya masih memiliki hubungan keterkaitan dengan makna kias yang terdapat pada polisemi di Kamus Besar Bahasa Indonesia Edisi Ketiga. Kata-kata tersebut adalah menghargai, menjamur, membayangkan, dan membekali. Untuk kata menghargai, membayangkan, dan membekali hubungan makna dengan kiasan idiom atau metafora terlihat pada polisemi di bagian lema. Untuk kata menjamur, hubungan makna metafora dengan kiasan terlihat pada polisemi di bagian sublema.

\subsection{Karakterisitik Verba Aktif Berderivasi Nomina ke Verba}

Selain melihat keberadaan makna kiasnya, peneliti menemukan karakteristik kata-kata berderivasi nomina ke verba yang mengalami perubahan makna. Karateristik tersebut dilihat dari kemampuan mereka sebagai verba aktif secara morfologis untuk dipasifkan dalam tataran klausa atau kalimatnya. Hasilnya, tidak semua verba aktif dapat dipasifkan. Ketidakmampuan tersebut berdasarkan karakteristik kata berderivasi nomina ke verba seperti di bawah ini.
1. Verba aktif terletak di akhir kalimat atau klausa yang langsung dikenai pungtuasi berupa tanda titik (.) atau koma (,)

Di dalam karakter ini, peneliti melihat verba-verba aktif tersebut menduduki fungsi sebagai penerang dari subjek. Karakter ini tidak hanya terjadi pada verba aktif yang bersifat intransitif, tetapi juga pada verba aktif yang dikenai afiks $m e(N)-k a n$ atau $m e(N)-i$ yang seharusnya memiliki objek.

\section{Verba aktif mendahului preposisi}

Dalam karakteristik ini, verba aktif tidak dapat dipasifkan karena bersifat intransif dan tidak memiliki objek. Objek digantikan dengan keterangan pada karakteristik tipe ini.

\section{Verba aktif didahului konjungsi}

Ketidakmampuan verba aktif untuk dipasifkan pada karateristik tipe ketiga ini karena terjadi pelesapan subjek pada kalimat. Pelesapan terjadi karena pada kalimat tersebut terdapat dua buah klausa yang saling terikat.

\section{Verba aktif didahului verba lain}

Ketidakmampuan verba aktif tersebut untuk dipasifkan pada karakteristik tipe keempat ini karena posisi mereka mengarah pada keterangan yang menerangkan verba di depannya. Hal ini menunjukkan ada pelesapan konjungsi yang membuat dua buah klausa terikat menjadi satu buah klasa. 


\section{Verba aktif didahului subjek bukan pelaku}

Dalam karakteristik tipe kelima ini, ketidakmampuan verba aktif untuk dipasifkan karena subjek tidak dapat berperan sebagai penderita. Hal ini terjadi karena subjek bukan pelaku kegiatan, melainkan hal yang abstrak. Karakteristik ini menunjukkan subjek pelaku berpengaruh pada kemampuan aktif-pasif di dalam kalimat.

\section{Verba aktif bersifat ekuatif di dalam kalimat}

Karateristik tipe ini mengarah pada verba aktif yang berperan sebagai penyambung antara pokok dengan rincian (ekuatif). Verba aktif tersebut tidak dapat dipasifkan karena kata-kata setelahnya merupakan definisi atau pemerinci dari kata-kata sebelum verba aktif sehingga tidak dapat digolongkan menjadi objek.

Verba yang tidak dapat dipasifkan sering kali memiliki lebih dari satu karakteristik penyebab. Untuk mempermudah penggambaran tentang penumpangtindihan karakter di atas, peneliti membuat tabel perbandingan di bawah ini.

Tabel 4 Perbandingan Karakteristik

\begin{tabular}{|l|l|l|l|l|l|l|l|l|}
\hline \multirow{2}{*}{ No. } & \multicolumn{2}{|c|}{ Kata } & \multicolumn{7}{|c|}{ Jenis Karakteristik } \\
\hline & & $\mathbf{( 1 )}$ & $\mathbf{( 2 )}$ & $\mathbf{( 3 )}$ & $\mathbf{( 4 )}$ & $\mathbf{( 5 )}$ & $\mathbf{( 6 )}$ & $\mathbf{( ? )}$ \\
\hline 1. & Mendarat & & $\mathrm{P}$ & & $\mathrm{P}$ & & & \\
\hline 2. & Menilai & $\mathrm{P}$ & & & & & & \\
\hline 3. & Merupakan & & & & & & $\mathrm{P}$ & \\
\hline 4. & Menangani & $\mathrm{P}$ & & & & & & \\
\hline 5. & Menyiasati & & & $\mathrm{P}$ & & & & \\
\hline 6. & Menghargai & & & $\mathrm{P}$ & & & & \\
\hline 7. & Meningkat & $\mathrm{P}$ & & $\mathrm{P}$ & & & & \\
\hline 8. & Mengular & & $\mathrm{P}$ & & & & & \\
\hline 9. & Melangkah & & & $\mathrm{P}$ & & & & \\
\hline 10. & Memanen & & & & & $\mathrm{P}$ & & \\
\hline 11. & Mengakar & & & $\mathrm{P}$ & & & & \\
\hline 12. & Meroket & $\mathrm{P}$ & & & & & & \\
\hline 13. & Merotasi & & & & $\mathrm{P}$ & & & \\
\hline 14. & Menjamur & $\mathrm{P}$ & & & & & & \\
\hline 15. & Memasarkan & $\mathrm{P}$ & & $\mathrm{P}$ & & & & \\
\hline 16. & Menggoreskan & & & & $\mathrm{P}$ & & & \\
\hline 17. & Melayari & & & $\mathrm{P}$ & & & & \\
\hline 18. & Menyikapi & & & & & & & $\mathrm{P}$ \\
\hline 19. & Membekali & & & & $\mathrm{P}$ & & & \\
\hline 20. & Melintasi & & & $\mathrm{P}$ & & & & \\
\hline 21. & Menggeliat & & & $\mathrm{P}$ & & & & \\
\hline 22. & Menyengat & $\mathrm{P}$ & & & & & & \\
\hline Keterangan: \\
،"” menunjukkan karakterisistik terdapat pada kata tersebut & & & \\
\hline
\end{tabular}

Penindihan karakteristik di atas menandakan bahwa karakteristik setiap kata berderivasi nomina ke verba pada data memiliki kemungkinan untuk berubah-ubah. Hanya ada satu kata yang karakteristiknya tetap, yaitu merupakan. Kata merupakan merupakan verba aktif yang sama sekali tidak dapat dipasifkan karena sifatnya yang ekuatif.

\section{SIMPULAN}

Total jenis kata yang mengalami derivasi sesuai prosedur penganalisisan sebanyak 44 jenis, 20 jenis untuk idiom dan 24 jenis untuk metafora. Jenis-jenis kata yang maknanya bersifat idiomatis adalah membentuk, menggeliat, merakit, mengeksekusi, mendarat, menyusun, mencetak, menilai, mendikte, merupakan, menggambarkan, menempatkan, memusatkan, membuahkan, mengarahkan, mengatasi, menangani, menempati, menyiasati, dan menghargai. Jenis-jenis kata yang maknanya bersifat metaforis adalah meningkat, mengular, mematok, memberangus, melangkah, memanen, mengakar, meroket, 
menyengat, merotasi, menjamur, membayangkan, meningkatkan, mengerahkan, memasarkan, mengendalikan, menggoreskan, membalikkan, melayari, menyikapi, mengendarai, membekali, menyelimuti, dan melintasi.

Kata turunan yang maknanya dianggap bersifat idiomatis dapat dilihat dari ketidakmungkinan makna turunannya untuk dikembalikan pada makna kata dasarnya. Hal tersebut terjadi karena makna turunan kata itu tidak memiliki sangkut paut dari makna kata dasarnya. Hal ini menunjukkan kata turunan yang sifatnya idiomatis adalah kata-kata yang membentuk makna baru berdasarkan konteks kalimat yang melingkupinya.

Kata turunan yang sifatnya metaforis merupakan kata-kata yang mengalami pergeseran makna dari kata dasarnya. Makna kata turunan dianggap bergeser dari makna kata dasar jika tidak mengambil keseluruhan komponen makna dari kata dasarnya. Makna kata turunan yang bersifat metaforis hanya mempergunakan atau memperbandingkan sebagian aspek komponen makna dari bentuk dasarnya untuk diterapkan dalam makna yang sesuai dengan konteks kalimat.

Dari keenam karakteristik verba aktif yang tidak dapat dipasifkan, ada beberapa kesimpulan peneliti mengenai kemampuan sebuah verba aktif untuk dipasifkan. Pertama, verba aktif tersebut harus memiliki objek. Kedua, subjek dari verba aktif tersebut harus jelas dan tidak dilesapkan. Ketiga, subjek yang mendahului verba aktif tersebut harus mengarah pada pelaku atau pembentuk kegiatan.

Dari penelitian yang dilakukan, banyak kata-kata berderivasi nomina ke verba yang maknanya sudah tidak dapat dikembalikan ke makna leksikalnya. Sebagian besar, makna idiom ataupun metafora yang ditemukan peneliti merupakan bentukan dari konteks kalimat data sehingga tidak ditemukan maknanya pada sublema kata tersebut di dalam Kamus Besar Bahasa Indonesia Edisi Ketiga. Hal ini menunjukkan ada perkembangan makna yang dihasilkan surat kabar harian Kompas. Perkembangan makna secara derivatif secara tidak langsung menandakan perkembangan bahasa ke arah positif di dalam masyarakat.

\section{SUMBER DATA}

Tim Redaksi Harian. 2013. Kompas (tertanggal 14 Januari 2013). Jakarta: Kompas Gramedia.

\section{DAFTAR PUSTAKA}

Alivea, N dkk. 1991. Bahasa Indonesia: Deskripsi dan Teori. Jakarta: Kanisius.

Alwi, Hasan dkk. 2003. Tata Bahasa Baku Bahasa Indonesia Edisi Ketiga. Jakarta: Balai Pustaka.

Arifin, Zaenal dan Junaiyah. 2009. Morfologi: Bentuk, Makna, dan Fungsi. Jakarta: Grasindo.

Berlian, Christian Wahyu. 2004. "Makna Metafora dalam Bab 1, 2, dan, 3 pada Kitab Amsal”. Depok: Fakultas Ilmu Pengetahuan Budaya Universitas Indonesia.

Bloomfield, Leonard. 1992. Bahasa (terj.) Kuala Lumpur: Dewan Bahasa dan Pustaka Kementrian Pendidikan Malaysia.

Boiij, Geert. 2006. “Inflection and Derivation”. Amsterdam: Universitet Amsterdam Netherlands. 2007. The Grammar o Words Second Edition. New York: Oxford University Press, Inc.

Candrayani, Amalia. 1993. "Kajian Sintaksis dan Semantis Koordinator Korelatif Bahasa Indonesia”. Jakarta: Fakultas Sastra Universitas Indonesia.

Chaer, Abdul. 2008. Morfologi Bahasa Indonesia: Pendekatan Proses. Jakarta: Rineka Cipta. 2009. Pengantar Semantik Bahasa Indonesia. Jakarta: Rineka Cipta.

Christomy, Tommy dan Untung Yuwono (ed.). 2004. Bahan Bacaan Pengantar Metodelogi Penelitian Kebudayaan. Depok: Fakultas Ilmu Pengetahuan Budaya Universitas Indonesia. 
Teodora Nirmala Fau: Perubahan dan Pergeseran Makna dalam Kata-Kata ...

Dik, S.C. dan Vrije J.G. Booij . 1994. Ilmu Bahasa Umum (terj.). Jakarta: RUL.

Ermanto. 2006. “Afiks Men- dalam Bahasa Indonesia dari Perspektif Morfologi Derivasi dan Infleksi” dalam majalah Kolita (Konferensi Linguistik Tahunan Atma Jaya Tingkat Internasional) 4. Jakarta: Pusat Kajian Bahasa dan Budaya Universita Katholik Atma Jaya.

Fahtoni, Abdurarahmat. 2006. Metodologi Penelitian dan Teknik Penyusunan Skripsi. Jakarta: Rineka Cipta.

Fauziah, Meutia. 2010. “Metafora Sufisme Ruba’i Hamzah Fansuri. Depok: Fakultas Ilmu Pengetahuan Budaya Universitas Indonesia.

Haryanto, Ignatius. 11 Januari 2012. “Jacob Utama dalam Lintasan Sejarah Pers”. http://m.hidupkatolik.com/index.php/2012/01/11/jakob-oetama-dalam-lintasan-sejarah-pers, (diunduh 10 Maret 2013 pukul 20.05 WIB).

"History". http://www.kompasgramedia.com/aboutkg/history, (diunduh 10 Maret 2013 pukul 19.24 WIB).

Katamba, Francis dan John Stonham. 2006. Modern Linguistics: Morphology. New York: Palgrave MacMillan.

Kempson, Ruth. M. 1984. Semantic Theory. Melbourne: Cambridge University Press.

Keraf, Gorys. 2007. Diksi dan Gaya Bahasa. Jakarta: Gramedia Pustaka Utama.

Kridalaksana, Harimurti. 1999. “Tata Wacana Deskriptif Bahasa Indonesia”. Jakarta: Fakultas Sastra Universitas Indonesia. 2009. Kamus Linguistik Edisi Keempat. Jakarta: Gramedia Pustaka Utama. 2009. Pembentukan Kata dalam Bahasa Indonesia. Jakarta: Gramedia Pustaka Utama.

Kurnia, Inu. "Oplah Harian Kompas”. http://jogja-adv.com/strategi-beriklan/strategi-promosi/770/ oplah-harian-kompas/, (diunduh 10 Maret 2013 pukul 19.32 WIB).

Kushartanti, Untung Yuwono, dan Multamia RMT Lauder (ed.). 2005. Pesona Bahasa: Langkah Awal Memahami Linguistik. Jakarta: Gramedia Pustaka Utama.

Lakeoff, George dan Mark Johnson. 1980. Metaphors We Live By. Chicago dan London: The University o Chicago Press.

Leech, Geoffrey. 2003. Semantik (terj.). Jakarta: Pustaka Pelajar.

Lubis, Hamid Hasa. 1993. Jenggala Bahasa Indonesia. Bandung: Angkasa.

Lyons, John. 1979. Semantics Volume 1. Melbourne: Cambridge University Press.

Muslich, Masnur. 2009. Tatabentuk Bahasa Indonesia: Kajian ke Arah Tatabahasa Deskriptif. Jakarta: Bumi Aksara.

Pane, Armijn. 1953. Perkembangan Bahasa Indonesia. Jakarta: KITA.

Parera, Jos Daniel. 1988. Morfologi Bahasa Indonesia. Jakarta: Gramedia Pustaka Utama.

Purwo, Bambang Kaswanti (ed.). 2000. Kajian Serba Linguistik: untuk Anton Moeliono Pereksa Bahasa. Jakarta: BPK Gunung Mulia.

Pusat Bahasa. 2007. Pedoman Umum Pembentukan Istilah. Jakarta: Departemen Pendidikan Nasional.

Ramlan, M. 2001. Morfologi: Suatu Tinjauan Deskriptif. Yogyakarta: C.V. Karyono.

Saksomo, Dwi. 1985. Deskripsi Fungsi Afiks Derivasi dan Infleksi Bahasa Melayu Manado. Jakarta: Departemen Pendidikan dan Kebudayaan. 
Teodora Nirmala Fau: Perubahan dan Pergeseran Makna dalam Kata-Kata ...

Sartuni, Rasyid. 2001. Aplikasi. Bogor: Maharini Press.

Sarwoko, Tri Adi. 2007. Inilah Bahasa Indonesia Jurnalistik. Yogyakarta: ANDI.

Stowell, Tim dan Eric Wehrli (ed.). 1992. Syntax and Semantics: Syntax and The Lexicon. London: Academic Press, Inc.

Subroto, D. Edi. 1987. "Infleksi dan Derivasi: Kemungkinan Penerapannya dalam Morfologi Bahasa Indonesia" dalam majalah Linguistik Indonesia Tahun 5 Nomor 10. Jakarta: -. 2005. "Pembentukan Kata Derivasional dari Nomina Menjadi Verba dan Nomina Lain dalam Bahasa Indonesia" dalam Prosiding: Seminar Antarbangsa Linguistik Melayu (Salimo 5). Kuala Lumpur: Universiti Kebangsaan Malaysia.

Sudaryanto. 1993. Predikat-Objek dalam Bahasa Indonesia. Jakarta: Djambatan.

Sunoto. 1990. Sistem Derivasi dan Infleksi Bahasa Jawa Dialek Tengger. Jakarta: Departemen Pendidikan dan Kebudayaan.

Tarjana, Heribertus. 2005. “Meninjau Kembali Proses Derivasi/Transposisi dalam Bahasa Jawa” dalam KOLITA 3. Jakarta: Pusat Kajian Bahasa dan Budaya Universitas Katholik Atma Jaya.

Tim Penyusun Kamus. 2007. Kamus Besar Bahasa Indonesia Edisi Ketiga. Jakarta: Balai Pustaka.

Verhaar, J.W.M. 2010. Asas-asas Linguistik Umum. Yogyakarta: Gadjah Mada University Press. 